\title{
Location Orientation of Organic Stores in Low Demand Areas: A Case Study of a Niche Market
}

\author{
*BeyzaGültekin ${ }^{1}$, María D. De Juan-Vigaray², Ana Espinosa Seguí ${ }^{2}$ \\ ${ }^{1}$ Hacettepe University, Beytepe-Ankara, Turkey \\ 2University of Alicante, Spain \\ *beyza@hacettepe.edu.tr
}

\begin{abstract}
This research provides a case study of a niche market in Marina Alta and Marina Baja counties located on the coast of the province of Alicante, Spain. These counties attract foreign residents from Germany, United Kingdom, and Scandinavia who are the frequent consumers of organic products. Accordingly, retailers choose the store location based on demand for organic products and detects a niche market in Spain. In addition, the study reveals the consumption patterns of organic-oriented consumers. In-depth interview is conducted with store managers and a researcher-administered survey is applied to the customers to identify the market. The study reveals the relationship between the presence of foreign residents who are more familiar to organic products and organic retailers' choice of store location. Results are given and discussed.
\end{abstract}

Keywords: Niche market, organic market, retailing, case study, Spain

\section{Introduction}

Organic production is a system of "farm management and food production" without harming the environment, following sustainable agricultural methods to protect the future of human, plant and animal health. By this way, organic production helps to preserve and progress the productivity of the land, health of human, plants and animals (Hughner et al., 2007). The organic market that started in mid-1990s (Finch, 2006) has dramatically grown in Europe along the last years. The European market for organic food represents $1.5 \%$ share of the total food market and amounts approximately $€ 20$ billion (European Court of Auditors Special Report, 2012).Consumption and production of organic products in Europe is growing $10-15 \%$ yearly (Finch 2006).This may be a natural consequence of several food crisis such as mad cow disease, hormone-laced milk, and e-coli infected food (Finch 2006), consumers' growing concern for feeding habits, changes in the consumers' lifestyle (Vlosky, Ozanne, and Forteno, 1999; Brugarolas and Rivera, 2002), and more available information(Straughan and Roberts, 1999). In addition to the consumer related factors, producers and retailers who make consumers benefit from advantages such as variety of products, convenience to buy, information flow and customer service (Coughlan et al., 2006) try to enlarge the market of the organic products. In Europe, differences in the perception and concern about organic food and mainly the purchasing power variation between countries have shaped two main markets with different speed of growth in the last decades (Chan and Lau, 2000).

North and Central Europe have developed intense distribution for organic products, with a high participation of mass retailers whereas Spain and other countries in the South have been specialized on the production of these products. In addition, producer countries that are located in the South have a lower consumption rate than the countries in the North. Although increase in the organic food consumption increased in terms of value and volume along the last decade (Follows and Jobber, 2000), absolute figures of consumption in Spain are still very low (Chamorro, 2004; Munuera and Pemartín, 2006). Parallel to this view, the purpose of this study is to examine whether there exists a relationship between the presence of foreign residents living in Marina Alta and Marina Baja who demand for organic products and organic retailers' concentration. In addition, the study reveals the consumption patterns of organic-oriented consumers. According to the purpose of the study, firstly market situation of organic products was examined. Moreover, reasons of consumers refraining from purchasing organic products were revealed in order to explain the Spanish retailers focus on niche market in Marina Alta and Marina Baja. In this context, methodology is composed of two parts explaining the consumer and retailer side. Finally, results were given and discussed. 


\section{Literature}

Organic Market: Although Spain was the European leader in terms of organic food production (Ministry of Rural and Marine Environment (MARM), 2010) and agricultural land reaching more than 1,300,000 hectares (European Court of Auditors Special Report, 2012), the consumption of organic products is low in domestic market (Albardíaz, 2000) which amounts $€ 600$ million. Organic market reaches more market share and more consumption rate in most of the countries than in Spain. Consumption rate (inhabitant/year) is the lowest in Spain, which is also below the European average (International Federation of Organic Agriculture Movements (IFOAM), 2012).According to Chamorro (2004), the average ticket of organic products in Spain is just $5.6 €$ whereas European average is $24.6 €$, which shows the low consumption of Spanish people in each purchase. Organic product consumption measured with "inhabitants per year" in Spain is very low in comparison with other countries such as Germany and UK (MARM, 2010). Germany is the leader (Baker et al., 2004) in terms of consumption which amounts $€$ 5.300 million with $3.1 \%$ market share (MARM, 2010). Although Germany is the market leader in Europe, market share also depends on the product category. Even in the same product category, market shares may vary depending on the product(Richter and Hempfling, 2003).

Organic Products -Niche Market: There is a trend in new markets to target the main consumer segment (Brugarolas and Rivera, 2002). Whether mass marketing methods are used in the distribution of organic products bringing high volumes of sales, convenience and technology, it would contradict to the organic philosophy (Latacz-Lohmann and Foster, 1997). Even the organic market growth rate has increased, the market is still regarded as a niche (cf.Kottila and Rönni, 2008). Based on this, organic product retailers can apply niche marketing as "product line" and "geographic" specialization (cf. Dalgic and Leeuw, 1994). By this way, instead of high volumes of sales, high profit is expected from niche (cf. Dalgic and Leeuw, 1994). Demand for organic products is not homogeneous and consumers are not purchasing all types of organic products at the same level (Kottila and Rönni, 2008; Loureiro and Hine, 2002). For example, market share of organic potatoes is $4.9 \%$, whereas $0.8 \%$ for cheese in Germany (Richter and Hempfling, 2003). Therefore, it is very difficult to find the right niche since the main problem of this decision is the heterogeneity of consumers, their lifestyles, and habits of consumption. Because of the low consumption rate of organic products in Spanish market, some Spanish retailers performed niche marketing strategies to reach more homogeneous consumption patterns.

Sanjuán et al., (2003) reported "consumers' willingness to pay differs among segments, products and cities". In addition, consumers buy organic products based on different reasons with different level of priorities depending on the country they live (cf. Squires et al., 2001). The Theory of Market Choice Behavior (cf. Finch, 2006) describes the consumer behavior, which is driven by consumption values instead of product features. Concern for health, environmental consciousness encourage demand for organic products (Squires et al., 2001; Pearson and Henryks, 2008), quality of organic products (Pearson and Henryks, 2008), "confidence in organic production" (Achilleas and Anastasios, 2008) and mistrust in non-organic production methods are the factors that motivate consumers buy organic products (Squires et al., 2001). Consumers mention health as the prior motive for purchasing and consuming organic products (Squires et al., 2001; Padel and Foster, 2005; Hughner et al., 2007).

Organic products-Price: Higher prices of any category or type of organic products compared to conventional products might be the main reason of low market share (Jones et al., 2001; Hughner et al., 2007). In addition, customers generally state the higher prices of organic products for their not buying (Jones et al., 2001; Hughner et al., 2007).Spanish people also declared high prices of organic products as their first limitation for their buying (Soleret al., 2002). Even consumers with positive attitudes towards organic consumption do not want to pay high prices for organic products (Sanjuánet al., 2003). In contrast, Jones et al. (2001) stated that customers who purchase organic products can bear high prices and parallel to this view Ngobo (2011) added the consumers of organic products generally being "less price-sensitive". Being a niche market, low consumption and production rates of organic products result in higher costs in terms of "handling, distribution, and marketing costs" compared to conventional methods since producers cannot reach economies of scale (Jones et al., 2001).

Organic products-Distribution: Organic products are distributed through many types of retailers (Pearson and Henryks, 2008). In most Western European countries, growth of consumption relates to the 
channels of distribution such as the existence of mass retail formats and independent organic shops (Alonso et al., 2000). In Central Europe, the organic consumption culture was created with an appropriate distribution strategy. Mass retailers such as supermarkets or hypermarkets distribute organic products in most of the European countries (IFOAM, 2012).Although organic products are in general distributed through supermarkets in Europe(Kottila and Rönni, 2008), customers express their not preferring to buy from and mistrust for those types of retailers (Padel and Foster, 2005). Soler et al. (2002) stated thatconvenience and/or location problems of the organic products may be the reasons of low consumption in Spain. For the customers who prefer supermarkets for their organic product purchase stated the importance of convenience (Padel and Foster, 2005). Convenient place for organic products and/or availability of them in many outlets might increase demand and demand for organic products increases the availability of organic products, which in turn may result in "push" and "pull" effects and high market share. In other words, "distribution causes market share and market share causes distribution" for fast moving consumer goods (Reibstein and Farris, 1995).

Organic Products-Promotion: Lower levels of awareness of Spanish people about the difference between organic and conventional products might result in not purchasing (Soler, et al., 2002). Although Pearson and Henryks (2008) asserted that organic products are well known by their production process "without artificial chemicals". In general, consumers' knowledge about organic products being low might stem from the absence of activities to educate the consumers and promote the products (Hughneret al., 2007; Squires et al., 2001).Parallel to this view, Hughneret al. (2007) added that inadequate promotional activities for organic products affected consumers negatively. The possibility of the purchase of organic products will increase whether organic products are promoted effectively such as providing information and displaying (Latacz-Lohmann and Foster, 1997). Besides, based on their focus group research Padel and Foster (2005) reported that organic stores are known by their 'knowledge' and information about the 'organic certification process' is demanded by every customer without depending on their purchasing and not purchasing organic products. As the supply increases, consumers might be more price sensitive which would lead to the education become the key to increase demand for organic products (Latacz-Lohmann and Foster, 1997)and would encourage non-buyers which is a 'large potential' for producers and retailers to enhance the market (Pearson and Henryks, 2008).

Research Questions: It is important to mention the importance of a market niche in the starting of a new store, even though when the demand is low. Moreover, the process of launching stores in a niche market have not been or rarely studied. Based on the purpose the study, following research questions were formed:

- RQ.1. a. How have organic retailers explored a niche market?

- RQ.1.b. Is there a relationship between higher densities of organic stores and the presence of foreign residents who are familiar to organic consumption?

- $\quad$ RQ.2. What are the problems of the stores operating in a niche market?

- RQ.3.What factors are important for the customers while purchasing organic products?

\section{Methodology}

Sampling and Data Collection Procedure: This study used qualitative and quantitative research techniques based on the data collection method, which has twofold: retailer and customer side. Firstly, from retail side, five store managers were in-depth interviewed. Open-ended questions were used in the in-depth interviews parallel to the purpose of the study that each took one to two hours. Information given by the store managers interviewed were quoted literally in the text and codified as ORG. For example the first organic store manager was shown as ORG1. Secondly, face-to-face survey was conducted. Sample was composed of customers of organic products who are from UK, Norway, Germany, Sweden, and Spain by using non-probabilistic convenience sampling. Data were collected from March to April 2010avoiding any sales period or specific circumstances that could affect consumer behavior. Those persons, who declared that they have never bought any organic products before the research were eliminated from the analysis. The final sample of customers was87.Demographic variables of the customers are given on Table 1. Demographics of the participants indicate that the sample is composed of mostly females, and their age ranges from 27 to 82 years. $66 \%$ of the sample was from Spain. 
Table 1: Demographic Variables of the Sample

\begin{tabular}{llllll}
\hline Variables & $\mathbf{N}$ & $\mathbf{\%}$ & Variables & $\mathbf{N}$ & $\mathbf{\%}$ \\
\hline Gender & & & Nationality & & \\
Male & 21 & 24 & Nordic & 7 & 8 \\
Female & 66 & 76 & German & 5 & 6 \\
& & & British & 15 & 17 \\
Age & & & French & 3 & 3 \\
$27-35$ & 11 & 13 & Spanish & 57 & 66 \\
$36-45$ & 20 & 23 & & & \\
$46-55$ & 33 & 38 & & & \\
$56-65$ & 17 & 19 & & & \\
$66+$ & 6 & 7 & & & \\
\hline
\end{tabular}

Data was collected in Marina Alta and the Marina Baja, the two counties in the province of Alicante with higher proportion of foreign residents of the whole area. Moreover, Hamm and Gronefeld (cf. Naspetti and Zanoli, 2009) stated the importance of the Northern part of Europe in terms of higher levels of organic product consumption. In addition, whether Nordic and German-speaking countries are excluded consumer demand for organic food is still very low in Europe (cf. Naspetti and Zanoli, 2009). Based on those issues it might be questioned whether retailers see a potential for organic products and choose the location for their stores in Marina Alta and Marina Baja.

\section{Analysis and Results}

Retailers: decision to operate in a niche market and features of the niche market: Based on the indepth interviews, location strategies of the organic retailers were analyzed. The market was defined as having low demand, high costs in terms of prices from suppliers and short life cycle of the grocery products. Before starting the business, the retailers intended to guarantee the stock turnover which has been related to the strategy of retailers and the quality of their products. For that reason, organic retailers firstly applied niche marketing by targeting coastal area of Alicante and focused their attention on foreign residents who are aware of and are familiar with organic products. In other words, retailers in Marina Alta and Marina Baja realized potential demand for their businesses in a small market. ORG 1 commented as follows:

"We came to the Marina Alta because of the foreigners. They helped us at the beginning, because Spanish didn't come into our shop at all. A lot of people did not know what we were selling and they thought that we were just an expensive grocery shop".

In addition, since those customers from other European countries are more ecologically educated and are more knowledgeable than the Spanish people about products, they helped retailers to establish better stores at the beginning. ORG 4 pointed out:

- "Since some of our packaged food comes from Italy, Germany, and France, they (foreign customers) just take the products and come to pay to the cash desk. It is so different when some Spanish consumers come... I have to teach them from the very beginning... There are some products that they do not know at all... and they are curious... so, it is like teaching someone who does not know anything about your lifestyle! It is stimulating also, but I have to admit that it is easier with foreigners, except trying to speak with them in English!".

In fact, the main problem which attack organic grocery retailers was the ignorance of the organic products. In this area this problem was bigger, as ORG 3 said:

- "Marina Alta has small towns and villages all around, which are specialized on tourism activities, but anything else... The environmental-friendly culture is scarce and Spanish people living in this area do not know a lot about this kind of shops. We have had to teach Spanish consumers what an organic product is. So, we had to prepare some seminars, focused on what is organic and what is not... Last year, we prepared a very successful seminar about new cooking styles. By doing this 
course, we were able to enlarge our number of clients. It was very successful! But we could not measure our success on gaining new clients, of course!"

Some other interviewees admitted that the environmental-friendly infrastructure was decisive for opening their stores. ORG 5 said:

- "In Alfaç del Pi (located on Marina Baja county) that is the only organic hotel of the region, and the first one of Spain. Moreover, the Waldorf School follows ecological principles and teaching staff and pupils' families look for organic natural food in the surroundings [...] It doesn't matter that the bulk of consumers do not know a lot about organic food, but at least, in this small area we have our place. I moved here because I wanted that my children came to Waldorf school. So the first idea I had when I saw the scarcity of organic offer in the area, was to run this business".

Parallel to this view, ORG 2 added:

- "It was encouraging for me to know that someone had made a great effort for educating this area with ecologic principles, as the hotel, some private seminars or the Waldorf school [...] I knew that the hinterland of my shop was very limited, in terms of geographical distance and population, but it was very nice to see how the area knew more about organic food than the big cities in the province... In fact, I know more shops in the county than in the rest of the province and mostly, they work better and none of them has closed down."

It can be interpreted that these preconditions were essential for retailers, who staked their location decision taking into account the potential of the existence of a small market niche. However, foreign population was not their target customers and retailers have used the presence of a more ecological educated community for settled down their store and be focused on the attraction of new clients. Therefore, the location of these stores was determined by the presence of a small niche market, which was able to speed up the settlement of the stores at the beginning. As ORG 2 commented:

- "I came from France ten years ago, and there I participated in an organic consumption cooperative. In France, organic consumer demand is very well organized and prices and offer are quite good established. I came here with my two little children and I did not have any offer at all of organic products [...] So... I opened my own shop! [...] Of course, I knew that Spain was very slow with the introduction of organic food consumption, but that was my objective: make more visible to Spanish people who have problems about standard food...with my limited possibilities... but it is really difficult [...] I am pretty sure that the Hotel and the School are not located here just by chance... There is a demand... small but definitely, a demand for our products...".

Whether these stores have problems with preserving the products and the quality of them, ORG 5 commented:

- "Every grocery store has problems with the maintenance of fresh products, because you need to have a constant turnover in order to offer the best quality with the lowest prices. If not, quality falls down, consumers are not satisfied, and we do not earn any benefit with our products... But here, in our shop, maintaining fresh our organic vegetables and fruits are much trickier, since we cannot use any insecticide... Furthermore, an organic product has a shorter life than a standard one, so we should need a quicker turnover."

In fact, the opposite happened and this lower turnover provoked smaller orders, which put up the prices of products. Since the market was quite small in the area analyzed, retailers had to manage with higher prices and lower margins of profit. ORG 3 complained about that:

- "How can we maintain our shops if prices are so high and we are always fighting for attracting new consumers? It is impossible! When I have to place an order, I do not take more than three or four units... That is why I am not reducing my costs!"

In conclusion, managers of organic stores experiences distribution channel problems such as having high costs low demand and not being able to reach economies of scale. In other words, retailers operating in a niche market have problems such as the lower amount of customers, stock turnover, and the high prices, which are typical features of a niche market.

Customer: factors related to organic store choice: Researcher-administered survey was conducted to the customer sample. Participants were requested to answer the questions based on their recent 
purchase. More than seventy percent (72.1\%) of consumers reported that they bought one or more than one per week, $16 \%$ of consumers once every two weeks and the rest of them (3.5\% and 5.8\%respectively) preferred to buy once a month or one or few times a year. Frequency of purchase of organic products and nationality of participants (being Spanish or not) is not related to each other (Chi-square: 5.411; d.f. 4; $\mathrm{p}>0.10$ ).

Participants were asked to choose the main reason of their choice of organic stores in the nominal scale such as liking the quality of products, convenience of the store, price level, promotional activities, assortment, like to be environmental friendly, and other reasons. There were no significant relationship between the nationality and the reason of purchase because of liking the quality of products (Chi-square: 2.376; d.f. $1 ; \mathrm{p}>0.10$ ). Most of the participants either Spanish (39 participants) and Non-Spanish(22 participants)stated the reason of their choice of the shore as "liking the quality of the products". Moreover, six (2 Spanish; 4 Non-Spanish) and seven (5 Spanish; 2 Non-Spanish) participants stated the importance of "environment" and the "assortment" respectively for choosing organic stores. But there were no statistical significant relationship between the nationality and environmental reasons of choosing organic stores (Chi-square:1.699; d.f.1; p>0.10).Additionally, it was not found any relationship between nationality of the customers and assortment's being important for the choice of organic stores (Chisquare:0.515; d.f. $1 ; \mathrm{p}>0.10$ ).

In addition, there were not any significant relationship between the nationality and convenience (Chisquare: 0.128; d.f.1; p>0.10). Four participants (2 Spanish, 2 Non-Spanish) stated the importance of convenience factor in their choice. None of the participants mentioned prices of the products and the promotional activities as a motive to buy. Although the rest of sample (35 participants; 19 Spanish, 16 Non-Spanish) indicated other motives in their decision to buy in organic stores, mentioning other factors was not related to their nationality (Chi-square: 0.454 ; d.f.1; $p>0.10$ ). Other findings of this research based on customers are as follows: in terms of the reasons of buying organic products $6.8 \%$ of customers reported "health issues", 9.2\% of the participants stated "environmental motives", 9.2\% indicated that it was due to the "customer service", 5.7\% stated the reason as the "variety of products". The rest argued another series of reasons as the convenience $(4.6 \%)$, the quick checkout $(2.3 \%)$, and the prices (1.1 $\%)$.Additionally, almost all consumers (96.6\%) interviewed indicated" they would recommend" organic products to their family and friends. Regarding the products that are mostly preferred by the consumers were those of nourishment, especially bread, dairy products, chocolate or coffee. Following, the beauty $(28.7 \%)$ and household care $(16.1 \%)$ products can be found. Finally, participants indicated that clothing $(1.1 \%)$ is not really the category of products that they enjoy the best, just for the fact that those are organic in nature. Consumers prefer multi-channels in their organic product purchases. The retail formats mentioned were especially the supermarkets with the preference of 80 participants. Specialty stores are the chosen format by 10 participants of the sample, whereas only four participants prefer the hypermarket. The rest six participants' preferences are other options such as Internet, telephone or catalogues. Finally, concerning the number of products bought, $57 \%$ of the interviewees indicated that they usually buy an average of four products in every purchase, opposite to the rest indicate that they are use to buy between five and nine different products. The average price of the purchase ticket is $18.44 €$, with a standard deviation of 17.38. Being the minimum $1.87 €$ and the maximum of the basket of purchase $84.69 €$.

\section{Conclusion, Discussion and Limitations}

Researchers interviewed (in-depth interview) the managers of those organic stores located in the area and researched administered survey was conducted to consumers of organic products. Since the consumption level is low, retailers that are specialized in organic products experience difficulties. Organic products market has not experienced a quick rise in supply and demand, which is blocking the expansion and modernization of these products value chain. This modernization would mean economies of scale and reduction in costs, which may in turn lower prices. In this context, Spanish retailers have tried to concentrate on the niche market to be able to supply organic products that are still in some areas scarce and not so well known yet. By this way, some organic specialty stores located in Marina Alta and Marina Blanca, coastal and tourist areas in Spain have made good use of the presence of small foreigner communities that are more familiar with and used to organic products. Based on in-depth interviews with store managers, retailers give importance to the customer and the market (Dalgic and Leeuw, 1994). Having a "modern marketing" perspective, retailers try to meet the needs and wants of customers better 
than other firms (Kotler and Armstrong, 2008:10) which results in added value for customers such as customer service (Dalgic and Leeuw, 1994), convenience, and assortment. Because of that benefit, organic retailers may have high margin (Dalgic and Leeuw, 1994), avoid competition/confrontation with larger competitors, and devote its energy to serving a unique market (Dalgic and Leeuw, 1994).

Insufficient knowledge of consumers about organic products has a role on the low level of consumption (Hughner et al., 2007). Interviewed retailers declared their knowledge about the local market and are able to provide a wide and deep market overview. Besides, store managers acknowledged the low level of ecoculture for organic products in Spain. Store managers interviewed emphasized the importance of their enlightening or educating customers. In other words, they stated the role of specialty stores as the form of "eco-instructors" in those markets. In such a way, store managers provide advice and more information concerning those products and creating information flow (Coughlan et.al, 2006: 52) for the customers. This finding is parallel to Padel and Foster (2005), reporting the creation of "education" advantage of specialty stores. Customers' indicating homogeneous reactions can be a good example for a niche market. The reasons of customers choosing organic stores are not related to nationality in this sample. Moreover, customers of organic products stated the main reason of their choice of organic stores as the positive evaluations about the quality of products and the convenience of those stores. This finding is parallel to the findings of Padel and Foster (2005) reporting the importance of specialty stores selling organic products because of creating convenience, quick checkout. Convenient place for products also increases demand especially for fast moving consumer goods (Reibstein and Farris, 1995).

Moreover, customers did not mention promotional activities and price as a reason to choose organic stores. Since price is one of the main reasons of not purchasing organic product (Ngobo, 2011), this finding is supporting the literature. In addition, since the demand is inelastic, "sales promotion and intensive distribution are not effective marketing instruments when it comes to increasing the number of buyers" in terms of organic products (Ngobo, 2011).In addition, choosing specialty store type of retailers launching organic products can be an advantage for retailers since consumers have "higher trust of" specialty stores "over" supermarkets (Padel and Foster, 2005). It is also interesting that customers not mentioning about the health factor in their choice of organic products. Sanjuánet al. (2003: 134) reported that "Spanish diet is quite representative of the Mediterranean diet, which has been proved to be healthier than that existing in northern and central European countries". In addition, Marina Alta has been voted as one of the healthiest places to live by the World Health Organization (2010). Based on these explanations, since Spanish people can reach healthy food in their routine life, it can be asserted that "consumers are less worried about healthy food" (Sanjuánet al., 2003: 134). Spain is weakling in organic product market and other countries may be in the same situation or even behind. Therefore, further research is necessary to learn about the organic product channels, selling formats, demographics and psychographic consumer characteristics.

\section{References}

Finch, J. E. (2006). The Impact of Personal Consumption Values and Beliefs on Organic Food Purchase Behavior. Journal of Food Products Marketing, 11(4), 63-76.

Achilleas, K. \& Anastasios, S. (2008). Marketing aspects of quality assurance systems: The organic food sector case. British Food Journal, 110(8), 829-839.

Albardíaz, M. A. (2000). Comportamiento del consumidor hacia los alimentos ecológicos. Distribución y Consumo, Abril-Mayo, 56-57.

Alonso, A., Guzmán, G. \& Centit, M. (2000).Caracterización de la agricultura ecológica en España. Análisis de una estrategia de comercialización directa: es caso de la SCA el Romeral, Introducción a la Agroecología como desarrollo rural sostenible, Madrid, Oxford University Press.

Baker, S., Thompson, K. E., Engelken, J. \& Huntley, K. (2004). Mapping the values driving organic food choice: Germany vs the UK. European Journal of Marketing, 38(8), 995-1012.

Brugarolas, M. \& Rivera, L. (2002). Comportamiento del consumidor valenciano ante los productos ecológicos e integrados. Estudios Agrosociales y Pesqueros, 192, 105-121.

Chamorro, A. (2004). Estrategias de marketing para productos de alimentación ecológica. Ecoliva: olivicultura ecológica. IVM editerranean Conference of Green Olive and Olive Oil Ecology, 549553, Génave, Spain. 
Chan, R. K. \& Lau, L. Y. (2000). Antecedents of green purchases: a survey in China. Journal of Consumer Marketing, 17(4), 338-357.

Coughlan, A. T., Erin, A., Louis, W. S. \& El-Ansary, A. I. (2006). Marketing Channels. New Jersey: Pearson Education.

Dalgic, T. \& Leeuw, M. (1994). Niche Marketing Revisited: Concept, Applications and Some European Cases. European Journal of Marketing, 28(4), 39-55.

European Court of Auditors Special Report. (2012). http://eca.europa.eu/portal/pls/portal/ docs/1/15290741.PDF, accessed on 17 August 2012.

Follows, S. B. \& Jobber, D. (2000). Environmentally responsible purchase behavior: a test of a consumer model. European Journal of Marketing, 34(5), 723-746.

Hughner, R. S., McDonagh, P., Prothero, A., Shultz, C. J. \& Stanton, J. (2007). Who are organic food consumers? A compilation and review of why people purchase organic food. Journal of Consumer Behaviour, 6(2-3), 94-110.

International Federation of Organic Agriculture Movements (IFOAM). (2012). http://www.ifoam.org/growing_organic/growing_organic_main.php, accessed on19 December 2012.

Jones, P., Clarke-Hill, C., Shears, P. \& Hillier, D. (2001). Retailing organic foods. British Food Journal, 103(5), $358-365$.

Kotler, P. \& Armstrong, G. (2008). Principles of Marketing. New Jersey: Pearson Education.

Kottila, M. R. \& Rönni, P. (2008). Collaboration and trust in two organic food chains. British Food Journal, $110(4), 376-94$.

Latacz-Lohmann, U. \& Foster, C. (1997). From niche to mainstream - strategies for marketing organic food in Germany and the UK. British Food Journal, 99(8), 275-82.

Loureiro, M. L. \& Hine, S. (2002). Discovering Niche Markets: A Comparison of Consumer Willingness to Pay for A Local (Colorado-Grown), Organic, and GMO-free product. Journal of Agricultural and Applied Economics, 34(3), 477-87.

Ministry of Rural and Marine Environment (MARM). (2010). http://www.mapa.es/ alimentacion/pags/ecologica/pdf/marketing.pdf accessed on 10 March 2010.

Munuera, J. L. \& Pemartín, M. (2006). El consumidor europeo de productos ecológicos. Distribución y Consumo, Enero-Febrero, 50-63.

Naspetti, S. \& Zanoli, R. (2009). Organic Food Quality and Safety Perception Throughout Europe. Journal of Food Products Marketing, 15(3), 249-266.

Ngobo, P. V. (2011). What Drives Household Choice of Organic Products in Grocery Stores? Journal of Retailing, 87(1), 90-100.

Padel, S. \& Foster, C. (2005). Exploring the gap between attitudes and behaviour: Understanding why consumers buy or do not buy organic food. British Food Journal, 107(8), 606-25.

Pearson, D. \& Henryks, J. (2008). Marketing Organic Products: Exploring Some of the Pervasive Issues. Journal of Food Products Marketing, 14(4), 95-108.

Reibstein, D. J. \& Farris, P. W. (1995). Market Share and Distribution: A Generalization, a Speculation, and Some Implications. Marketing Science, 14(3), 190-202.

Richter, T. \& Hempfling, G. (2003). https://www.fibl.org/fileadmin/documents/shop/1285supermarket.pdf, accessed on 17 August 2012.

Sanjuán, A. I., Sánchez, M., Gil, J. M., Gracia, A. \& Soler, F. (2003). Brakes to organic market enlargement in Spain: consumers' and retailers' attitudes and willingness to pay. International Journal of Consumer Studies, 27(2), 134-144.

Soler, F., Gil, J. M. \& Sánchez, M. (2002). Consumers' acceptability of organic food in Spain: Results from an experimental auction market. British Food Journal, 104(8), 670-687.

Straughan, R. D. \& Roberts, J. A. (1999). Environmental segmentation alternatives: a look at green consumer. behavior in the new millennium, 16(6), 558-575.

Squires, L., Juric, B. \& Cornwell, B. T. (2001). Level of market development and intensity of organic food consumption: cross-cultural study of Danish and New Zealand consumers. Journal of Consumer Marketing, 18(5), 392-409.

Vlosky, R. P., Ozanne, L. K. \& Fortenot, R. (1999). Conceptual Model of US consumer willingness-to-pay for environmentally certified wood products. Journal of Consumer Marketing, 16(2), 122-136.

World Health Organization. (2010). http://www.destinationmediterranean.co.uk/locations/ index.php?n=7\&s=19, accessed on 10 March 2010. 